\title{
AJRC
}

Australia - Japan Research Centre

\section{WHO PARTICIPATES IN CORPORATE INCOME TAX CONSOLIDATION? EVIDENCE FROM JAPAN *}

\section{AJRC Working Papers 03/ 2013 May 2013}

Kazuki Onji

Graduate School of Economics

Osaka University

\section{Abstract}

When a group of affiliated corporations have the option to file a single tax return based on a combined income, what types of groups would take up the option? This study empirically analyses decisions to participate in a single-jurisdiction consolidated tax filing. The data consists of 2,782 Japanese corporate groups headed by publicly-traded corporations observed over 2002-2007. Results indicate higher likelihood of participation among groups characterised by low correlation in returns among group members, high variance in returns, large number of subsidiaries, and losses accumulated in parents. The significant influence of variance and covariance of returns suggests that a consolidation scheme improves the efficiency of corporate income tax through reducing profit shifting. 
*I would like to thank Roger Gordon, Tue Gorgan and participants of the Second ANUJapan Public Economics Workshop for their valuable feedback. Miyoko Asai provided excellent research assistance. All remaining errors are my own.

\section{Keywords}

corporate group; profit shifting; survival analysis

\section{JEL Classification}

G34; H25; K34

\section{Suggested Citation:}

Onji, K. 2013. Who participates in corporate income tax consolidation? Evidence from Japan, AJRC Working Paper No. 3, April 2013. Australia-Japan Research Centre, Crawford School of Public Policy, The Australian National University.

\section{Address for correspondence:}

(E) ajrc@anu.edu.au

ISSN 07288409

ISBN 978-0-86413-356-4

The Australia-Japan Research Centre (AJRC) conducts research to explore and improve understanding of the economies and economic policy processes in Australia and Japan and both countries' strategic interests in the Asia Pacific economy.

The AJRC Working Paper Series aims to provide a forum for the exchange of topical research and contains the latest research and analysis on the Japanese economy, as well as the political economy, regional integration and trade. The views expressed in AJRC Working Papers are those of the individual authors and do not represent the views of the Australia-Japan Research Centre, the Crawford School, or the institutions to which authors are attached.

The Crawford School of Public Policy is the Australian National University's public policy school, serving and influencing Australia, Asia and the Pacific through advanced policy research, graduate and executive education, and policy impact. 


\section{Introduction}

"You could get rid of most of the confusion of trying to determine arm'slength prices ... by consolidating foreign affiliates" Stanley Surrey (sometimes in the $1930 \mathrm{~s})^{1}$

A consolidated filing regime (CFR) is a common tax policy. Currently, 14 out of the 34 OECD nations provide an option for a parent company to file a single tax return on behalf of its domestic subsidiaries and to pay taxes based on a combined income. A separate accounting regime (SAR) requires each affiliated corporation to file its own tax return. Practitioners understand CFR's chief benefit: by combining incomes from group members, losses are offset against profits automatically rather than being carried forward within each entity, removing incentives to shift profits across group members. CFR potentially reduces administration and compliance costs of arms-length transaction requirements (Mintz 2004; Cummings, 2011).

What determines firms' decision to participate in CFR? Do the structures of groupwide return matter? When returns are perfectly correlated within a corporate group, either none or all affiliated corporations make losses so the group would have little incentive to participate in CFR. Aside from casual observations, systematic study has been limited. ${ }^{2}$

\footnotetext{
${ }^{1}$ A paraphrase, reported in Cummings (2011). Stanley Surrey was a Harvard Law School Professor and a member of the Shoup Mission to Japan in the post-war reconstruction period.

${ }^{2}$ Oestreicher and Koch (2010) examine participation to Germany's loss transfer arrangement, an alternative system to provide immediate loss offset.
} 
This study aims to offer the first evidence relating the structures of group-wide return to the decision to participate in CFR.

The empirical analysis focuses on the Japanese CFR introduced in 2002. The Japanese tax system prior to the 2002 reform allowed for a group loss relief on a limited basis, ${ }^{3}$ but evidence from court cases and an econometric study (Onji and Vera, 2010) indicates that corporate groups engaged in within-jurisdiction profit shifting to offset losses. The 2002 tax reform introduced an optional CFR for the national corporate income tax. This policy change is relatively recent, compared to, for instance, the U.S. and France which introduced CFR in 1917 and 1988 respectively, and provides an opportunity to examine the reaction to the newly available option to participate in CFR. The scope of our study is to provide a case study based on the Japanese institution before the 2010 amendment. ${ }^{4}$ The external validity of the results would depend on institutional specificities, naturally, but the analysis does provide groundwork to conduct similar studies elsewhere.

The main sample consists of 2,782 corporate groups headed by publicly-traded corporations observed over the 6 years spanning FY2002-2007. ${ }^{5}$ Of this main sample, 181, or $6.5 \%$,

\footnotetext{
${ }^{3}$ Technically, the case law has established that intra-group transfers, such as subsidized loans, to be treated as donation for tax purposes. Donations are deductible from corporate income up to limit. This system contrasts with a formal system, such as in U.K., which requires offset to take place within a group of affiliates with more than $75 \%$ ownership.

${ }^{4}$ The 2010 amendment can be compared to the Tax Reform Act of 1969 in the U.S. in that it tightened SAR to limit tax avoidance opportunities involving group of controlled corporations.

${ }^{5}$ To be sure, corporate groups in our sample are not keiretsu which, in standard usage of the term, refers to a horizontal association of independent corporations, organized around a main bank, operating in diverse industries. Many of keiretsu originate from family-oriented conglomerates from the pre-Second World War era. A corporate group in this study refers to a group consisting of a parent company and its subsidiaries, is distinct from bank-centered horizontal keiretsu, and is a common organizational form in any modern
} 
participated in CFR during the sample period. To examine determinants of participation, we apply the survival analysis and estimate a discrete-time hazard model to relate participation decisions to measures of group-wide return structures, controlling for confounding factors. The survival analysis is sensible for two main reasons. First, the model allows for changes in circumstances that affect participation decisions. Second, the timing of participation varies and a hazard model is a natural way to capture the time variation.

A theory suggests that the structures of group-wide return influence the participation decision through affecting potential tax savings from participating in CFR. First is the correlation of returns within a group. When returns tend to move in the same direction, tax savings from intra-group offset are small, making CFR unattractive. Second is the variance of returns. A low probability of making any losses render the loss offset feature irrelevant. Third is the autocorrelation in own returns. A negative autocorrelation increases the utilisation rate of carried forward losses under SAR, reducing the tax disadvantage of SAR and, consequently, the incentives to participate in CFR. Forth is the number of subsidiaries. CFR imposes compliance costs and larger groups are more likely to make positive net gains from participation.

The results indicate a systematic relationship between participation decisions and tax incentives. First, we find statistically significant effects of within-group correlation in returns. Estimates indicate that a standard deviation increase in a correlation measure is economies. 
associated with 1.5-1.8 times higher participation likelihood. Second, the variance of return is significant. A standard deviation increase in variance is associated with 1.7-2.1 times higher participation. Third, the number of subsidiaries is significant. A unit increase in the number of subsidiaries raises the participation likelihood by 2.2-3.9\%. Lastly, a measure of losses carried forward by the parent is significant. A parent with carry over losses are 2.44.0 times more likely to participate. We did not find significant effects for autocorrelation and small business concessions. The effects of losses carried forward by subsidiaries remain inconclusive. The basic results are robust to a battery of robustness checks which employed alternative measures and allowed for individual specific effects. Overall, the results show a strong relationship between participation decisions and the structures of group-wide returns.

This study primarily contributes to the literature on the empirical analysis of profit shifting. The core focus of the profit shifting literature has been the important issue of the existence and extent of distortion caused by profit shifting by multi-national corporations (MNCs). ${ }^{6}$ The efficacy of policy instruments to address profit shifting has received small attention. ${ }^{7}$ Mintz and Smart (2004) look for a causal link from a joint filing of tax return to a reduction in profit shifting activities, and provide evidence from Canada. ${ }^{8}$ The empirical

\footnotetext{
${ }^{6}$ See Gordon and Hines (2002) for a review of the earlier literature.

${ }^{7}$ Eden, Valdez, and Li (2005) conduct an event study examining the impacts of penalties of non-compliance to arm's length rules on Japanese multinationals operating in the U.S. during the 1990s.

${ }^{8}$ Specifically, Mintz and Smart (2004) compare two types of multi-jurisdictional firms, one operating as a single entity and another operating multiple entities incorporated across Canadian provinces. The former type files a single tax return whereas the latter type files multiple tax returns. Unlike in CFR, which is not available in Canada, income consolidation arises from the choice of organizational form. They find that the tax-rate elasticity of corporate tax base is higher for multiple-entity firms than for single-entity firms, thus supporting a view that tax consolidation reduces profit shifting activity.
} 
approach in this paper complements the approach taken in Mintz and Smart (2004) who assume the choice of organisational form as exogenous (Gresik, 2012). By explicitly recognising the endogeneity in participation decisions, the present paper highlights potentially important mechanism through which a corporate tax system that allows for group taxation can improve efficiency: through the participation by firms with higher profit shifting motives. In theory, a group will participate if CFR reduces costs, including taxes, relative to SAR. Groups with larger cost savings are also those with higher motives to engage in profit shifting under SAR. By showing that the predicted tax savings to be systematically related to participation in CFR, this study offers evidence suggesting that income shifting among the participating groups declined. In this view, the introduction of CFR in Japan would have improved the efficiency of the tax system, though some qualifications apply. ${ }^{9}$

This paper is relevant in understanding the corporate tax consolidation within a jurisdiction, but the results also have bearing on the cross-boarder setting given the lack of evidence in that context. ${ }^{10}$ Multi-national corporations (MNCs) face strong incentives to offset losses

\footnotetext{
${ }^{9}$ The improvement would have been limited by two factors. First, the primary limitation aries from the small number of participants in CFR due to high compliance costs under CFR. Second, CFR participants may still be engaging in profit shifting to avoid local taxes on corporate income. CFR applies to the national tax, but not to the local taxes, so that participants still file separate tax returns on the local taxes for each group member. The participating groups therefore have incentives to shift profit to obtain immediate loss offset. The variation in local tax rates are not wide due to narrow bands on permissible tax rates imposed by the central government, so the incentives to exploit regional tax differential would be small.

${ }^{10}$ A lively literature developed in response to the European Union's (EU) proposal on the EU-wide consolidated tax base with formula apportionment (FA). The literature continues to accumulate theoretical analysis (e.g. Eichner and Runkel, 2011) and simulation studies (e.g. Devereux and Loretz, 2008), but empirical research remains few. Existing empirical studies on consolidation, whether under a multi- or single jurisdiction setting, are limited to costs, namely the behavioral response in form of distorted organizational forms, on sub-national taxes in Germany (Buttner, Riedel, and Runkel, 2011) and a national tax in Japan (Onji 2011). The benefits, on the other hand, are not well documented with an exception of Mintz and
} 
made in a company in one jurisdiction with profits from another jurisdiction, as in the European Court of Justice case on Marks and Spencer in 2005 highlights (Kalamov and Runkel, 2012; Haufler and Mardan, 2012); a dollar of profit shifting reduces tax liabilities in the order of 30-40 cents depending on tax rates. The group loss offset is the key benefit for MNCs in consolidating tax bases of affiliates. If a country extends the eligibility for CFR to foreign affiliates, and if participation is optional, which MNCs are more likely to take up the option? ${ }^{11}$ The answer depends crucially on institutional details. ${ }^{12}$ The results of this study lend support to the prediction that, other things being constant, participating MNCs tend to exhibit volatile returns with small intra-group correlation.

The rest of the paper is organised as follows. Section I analytically considers determinants of tax savings arising from participating in CFR. Section II describes the data and measurement issues. Section III outlines the empirical approach and presents results. Section IV concludes.

Smart (2004).

${ }^{11}$ The Rostenkowski-Gradison Foreign Tax Simplification Act proposed in 1992 incorporated an option to elect foreign affiliate to join CFR (Cummings, 2011). In 2004, Italy introduced CFR, which included worldwide consolidation for MNCs. EU has been considering taxing a MNC on the basis of a consolidated income of its subsidiaries residing within EU.

${ }^{12}$ One needs to be careful in generalizing an analysis on a single-jurisdiction consolidation. Under a multi-jurisdiction consolidation, tax revenues from MNCs needs to be shared among countries with different tax rates. Applying formula apportionment may distort location of real activities. A single-jurisdiction consolidation is but a special case where tax rates across jurisdiction are equal, so that firms face no incentive to exploit regional tax differentials by adjusting locations of real activities. 


\section{Theory}

\section{A Baseline model}

This section aims to outline explicitly how the structures of group-wide returns affect incentives to participate in CFR. To this end, we develop a simple model of a firm, consisting of a parent company and its subsidiaries, to develop intuition and to base a simulation analysis upon.

We consider a single jurisdiction with a flat tax rate on positive income to focus on profit shifting for purpose of offsetting losses. We therefore abstract from any possible shifting across jurisdictions. All member corporations in a firm are eligible for consolidation. The baseline static model will provide a basis for incorporating other considerations.

The firm consists of $J$ affiliated companies with 'true' before-tax profits of $\underline{y}=\left\{y_{1}, \ldots, y_{J}\right\}$, generated exogenously. The firm may engage in transfer pricing so that a reported profit $\left(\pi_{j}\right)$ may deviate from a true profit as follows: $\pi_{j}=y_{j}+\psi_{j}-c_{j}\left(\psi_{j} ; \gamma\right), \sum \psi_{j}=0 . \psi_{j} \gtrless 0$

represents profits shifted in/out from/to other members. $c_{j}($.$) represents the cost of shifting$ profits from $j^{\text {th }}$ company. As is standard in the literature, the shifting cost increases with amounts shifted at an increasing rate, provided that there exists a friction, represented by $\gamma$, such as restriction on transfer pricing. The cost function varies across companies, usually depending on size, so that a dollar of shifting is less costly for larger company. When there is no friction $(\gamma=0), c_{j}\left(\psi_{j} ; \gamma=0\right)=0$ for $\forall \psi_{j}$. 
The following equation describes the after-tax profit of the firm (П), as a group of affiliated companies.

$$
\Pi(\underline{\psi})=\sum_{j=1}^{J} y_{j}-T(\underline{\pi})-\sum_{j=1}^{J} c_{j}\left(\psi_{j} ; \gamma\right)
$$

$T(\underline{\pi})$ represents a tax payment as a function of reported profits $\left(\underline{\pi}=\left\{\pi_{1}, \ldots, \pi_{J}\right\}\right)$. Under SAR and CFR respectively, $T(\underline{\pi})=\sum \tau \max \left(\pi_{j}, 0\right)$ and $\tau \max \left(\sum \pi_{j}, 0\right)+k . \quad \tau$ is a flat tax rate on corporate profit. To capture compliance costs of filing CFR, the firm incurs costs $k$ when it chooses to file under CFR. A firm would strictly prefer CFR to SAR if $\Pi^{C F R}\left(\underline{\psi}^{*}\right)>\Pi^{S A R}\left(\underline{\psi}^{*}\right)$, where $\underline{\psi}^{*}$ indicates the optimal set of shifting that maximises the after-tax profit under respective regimes.

Note that in absence of compliance costs, the firm's profit is no smaller under CFR for any given choice of $\underline{\psi}$. Intuitively, this arises since tax bases under CFR are no larger than those under SAR due to the loss offset. We summarise this property in the following lemma.

Lemma 1 Suppose that the compliance cost in filing under CFR is zero $(k=0)$. Then

$$
\Pi^{S A R}(\underline{\psi}) \leqq \Pi^{C F R}(\underline{\psi}) \text { for } \forall \underline{\psi} \text {. }
$$

Proof: See appendix.

SAR makes little economic sense from a firm's viewpoint, according to Lemma 1, suggesting firms would usually participate in CFR. In practice not many participate in the Japanese CFR. This discrepancy between the theory and observed pattern indicates that some other 
forces are at work. A possible explanation highlighted in Lemma 1 is the cost of tax filing under CFR.

The firm's problem is to choose amounts of profit shifting to maximise after-tax profit in a given tax regime. In doing so the firm trades off costs of shifting against tax savings. Clearly the optimal choice under CFR when $\gamma \neq 0$ is $\underline{\widetilde{\psi}} \equiv\{0, \ldots, 0\}$ since there is no benefit from profit shifting while shifting incurs costs. Under SAR, the firm would choose $\underline{\psi}^{*}$ in a way that set marginal costs of shifting equal to marginal tax savings subject to the constraint.

A useful special case is when $\gamma=0$. Intuitively, when there is no compliance cost the firm offset losses against profit fully by shifting income, obtaining profit level equal to CFR. We summarise this property in the following lemma.

Lemma 2 Suppose that the compliance cost in filing under CFR is zero $(k=0)$ and profit shifting generates no costs $(\gamma=0)$. Then

$$
\Pi^{S A R}\left(\underline{\psi}^{*}\right)=\Pi^{C F R}(\underline{\widetilde{\psi}})
$$

where $\underline{\psi}^{*}$ is such that $\Pi^{S A R}\left(\underline{\psi}^{*}\right) \geqq \Pi^{S A R}(\underline{\psi})$ for $\forall \underline{\psi}$.

Proof: See the appendix.

In practice, when the enforcement of anti-avoidance rule is lax, or when a within-group loss-offset provision permits profit shifting, the cost of shifting would be small. In such a circumstance, CFR makes little economic sense, particularly when the compliance costs under CFR is non zero. Lemma 2 thus highlights that additional explanation for low adoption rate in Japan is low shifting costs under SAR. 
The above discussion leads to an observation useful in further analysis, summarised in the following proposition.

Proposition 1 Suppose that the compliance cost in filing under CFR is zero $(k=0)$. Then choosing CFR over SAR can generate, at most, tax savings of

$$
D=\Pi^{C F R}(\underline{\widetilde{\psi}})-\Pi^{S A R}(\underline{\widetilde{\psi}}) .
$$

Proof: See appendix.

In analysing the advantage of CFR, the possibility of profit shifting under SAR poses difficulty given absence of precise information on shifting costs. This proposition shows that the maximum potential tax savings $(D)$, is the difference between the two regimes in group profits in absence of shifting. Therefore, other things being constant, the factors that affect $D$ affect the choice of tax regimes. This value can be analysed without imposing specific functional forms on $c_{j}\left(\psi_{j} ; \gamma\right)$. To incorporate uncertainty in the model, we will consider next simulation analysis of $D$.

\section{B Simulation analysis}

The firm does not know ex ante whether choosing CFR reduces tax payments. Numerical comparisons of CFR and SAR are useful in incorporating uncertainty into analysis. An advantage of a numerical approach is in providing a simple way to examine the whole distribution of, and not just the means of outcomes. This section considers the potential maximum 
tax savings (which are sometimes losses) from participating in CFR relative to remaining in SAR.

In a baseline simulation, we generate random numbers representing before-tax profits of individual corporations, each belonging to a corporate group, drawn from a common distribution. We compute tax bases for CFR and SAR, apply a common tax rate of 30\%, and compute tax savings, corresponding to $D$, under various parameter values. In the base simulation we considered a moderately-sized group of 20 members. The sample size of simulations is 10,000 corporate groups. We initially focus on static setting, and incorporate dynamic considerations in latter analysis. The appendix details specifications.

Figure 1, Panel A shows the mean of tax savings per member is smaller for groups with higher expected before-tax return. This arises because the probability of making losses, and thus utilizing immediate loss offset under CFR, falls when expected returns are high. Likewise, tax savings are lower for a group with low volatility in before-tax return for the same reason. The simulation in Panel B plots tax savings for a range of variance in before-tax return, and shows a positive relationship between volatility and tax savings.

Panel $\mathrm{C}$ considers the size of a group. The group-wide tax savings is proportional to the number of group members since an addition of a member increases the chance to utilise losses from other members, or to utilise loss of that new member. The group size has an additional dimension. Panel D takes the simulation sample and plots a kernel density estimate of the tax savings per group members. The distribution of tax savings for large groups, with 50 
members, has a bell shape around the mean (solid line). While the means is the same, much of smaller groups, with 10 members, have zero or small benefits (long dashed line). This result arises since small groups have higher chances of not utilizing immediate loss offset due to the higher incidence of all members making profits (and none making profits). In other words, larger groups utilise immediate loss offset with more certainty.

Preceding simulations assume independence of business performance across affiliated companies. In reality, returns are likely to be correlated across affiliates. All group members, for instance, could be operating in the same industry and influenced by same industry events. The simulation in Panel E allows for correlation in returns within a group through incorporating a 'common shock' that affects affiliates but not non-affiliates. Panel E shows that tax savings to fall with stronger correlation. This is expected since a higher correlation means returns of affiliates tend to move in the same direction, resulting in less chance of utilising immediate loss offsets. With perfect correlation, there is no tax savings at all.

When CFR places restrictions on pre-consolidation losses, like in the Japanese case, a static analysis ignores a one-time cost of forgoing credits for accumulated losses. A survey of Japanese firms finds that businesses viewed the restriction on pre-consolidation losses as being the main disagreeable feature of the Japanese-style CFR (Ohkura, 2004). The expiration of pre-consolidation losses thus can out-weight the benefits from immediate loss offsets.

The simulation in Panel F considers a simplified example. It shows tax savings that arise 
in a single period from switching to CFR. ${ }^{13}$ The simulation considers the role of autocorrelation in returns under three loss-offset regimes in SA: no offsets, carry forward with one-year expiration, and carry forward without expiration. The lack of loss carry forward provides a baseline, showing that tax savings are positive and unrelated to the degree of autocorrelation. Allowance for loss carry reduces tax savings, except for the case of perfect autocorrelation. A longer expiration period reduces tax savings, as indicated by the solid line below the dotted line. Tax savings are positive with selected parameter values, but with low autocorrelated returns, a firm may end up paying more taxes in the first year of participation. Thus, groups with low autocorrelated return might find CFR to its disadvantage.

\section{Data}

\section{A Data sources}

We gathered information on CFR participants and the timing of participation based on a list of CFR participants constructed by Partners Inc., a consulting firm, from a review of securities reports filed between May 2008 and April 2009. ${ }^{14}$ The Japanese financial year (FY) typically runs from April through March and the latest information is from FY2008. The original list unfortunately does not contain the exact participation timing. We gathered the

\footnotetext{
${ }^{13}$ The simulation assumes a constant price level. Tax savings would be higher if we allow for inflation since a dollar of loss generated long time ago would worth much less today in real term.

${ }^{14}$ http://www.shinnihon.or.jp/knowledge/account_co/account/opinion/35/story/01.html, accessed April $19,2010$.
} 
information on timing from past securities reports filed by traded companies on the list. We located exact information for 221 companies and approximate information for 4 companies.

We obtained group characteristics from the Affiliated Company Data (ACD) published annually by Toyo Keizai. ACD is a directory of corporate groups, containing information on domestic affiliated companies of traded companies and large non-traded companies. Toyo Keizai conducts a survey and also examine securities report in the production of the directory. From this data source we can observe basic characteristics of member corporations, such as holding levels and industry classifications. One drawback of this data source is the coverage of financial variables. Variables are limited to basic financial characteristics, such as paid-up capital and after-tax profits, and many observations are missing. This data source however has a good coverage of basic company characteristics, such as location and ownership level. ACD is available at biennial frequency for FY2000, 2002, 2004, and 2006 for this research. Our analysis however is at annual frequency. To fill the data gap, we assumed ACD-based variables to remain constant for the subsequent financial year. This approach is sensible for the key variable of interest since year-to-year variation in the number of industry that a corporate group operates in should be small.

Financial information on parent companies was drawn from unconsolidated financial statements contained in Nikkei's NEEDS-DVD. NEEDS is available at annual frequency. 


\section{B Measurements}

\section{B.1 Autocorrelation and variance}

In theory, the variance as well as autocorrelation of profitability affects the relative advantage of CFR. A partial autocorrelation coefficient is a common measure of serial dependence (see, for example, Hamilton, 1994). We estimated an Ordinary Least Squares (OLS) regression on a parent company $i$ 's earning ratio on its first lag and a constant to obtain a measure of autocorrelation for group $i^{15}$ In this formulation, a variance of earning ratio consists of an autocorrelated component and an unexplained component. A variance of residuals from the autocorrelation regression is taken as a measure of variance in return. ${ }^{16}$

\section{B.2 Within-group correlation}

The main measure of within-group correlation in returns draws from observable attributes of group members. Practical and theoretical considerations drove this choice. Ideally we would like to estimate degrees of correlations in (true) returns directly, but as noted above, many financial information on subsidiaries are missing. Even when financial variables are available in $\mathrm{ACD}$, reported returns diverge from true returns if firms engage in profit shifting. Hence we consider utilising information on industry classifications and geographic locations.

\footnotetext{
${ }^{15}$ The earning ratio for each parent corporation is from NEEDS-DVD. The sample is annual observation spanning 1985-2007, and contains observations with minimum of 6 years of data.

${ }^{16}$ The coverage of financial variables for subsidiaries are unfortunately limited in ACD. This formulation assumes that participation decisions are mainly made on the basis of parents' financial characteristics.
} 
A group with most members operating in similar lines of activities are likely to have correlated returns since common industry shocks affect their returns. We would hence expect that, other factors remaining constant, more diversified groups tend to have less correlated returns among group members. We drew statistics on concentration from the industrial organisation literature. Common concentration measures include the sales share of top $n$ firms in a market (concentration ratio, CR) and the Herfindahl-Hirschman Index (HHI), which is a sum of squared shares of firms in a market. John and Ofek (1995) employ a HHI-based measure to measure diversification. In applying those concentration measures to the present setting, we counted the number of corporate group members from the same industry within a corporate group. We then divided the number of members in the same industry by the total number of members in a group for the computation of CR and HHI. The industry classification is similar to the 2-digit SIC, and is the Toyo Keizai classification (pre-1998 editions). Larger values of HHI indicate higher degrees of activity concentration. ${ }^{17}$

We also constructed the same measure based on headquarter locations of group members. For instance, a manufacturer may own sales subsidiaries that operate in many different localities. To the extent that local economic conditions affect sales, the returns would be less correlated for a group that operates nationally than for a group that operates locally.

\footnotetext{
${ }^{17}$ Alternative statistic to CR and HHI would be the coefficient of variation and the Gini coefficient. We did not consider the coefficient of variation, which is a ratio of standard deviation to mean, since it is a transformation of HHI. We have constructed the Gini coefficient in a preliminary examination but because this measure was highly correlated with other measures and was more computationally demanding we did not consider it in latter analysis.
} 
The second approach attempts to measure directly co-movements in returns among group members. We have considered a type of the diffusion index (DI) to measure co-movements in profitability. ${ }^{18}$ We defined this measure as follows: $D I \equiv\left|S^{+}-S^{-}\right| . S^{+}$and $S^{-}$is the share of group members with positive and negative profit respectively. DI takes on the value of 1 if either all group members are reporting profits or all are reporting losses - two cases in which the allowance for intra-group loss offset does not reduce tax liability. The values of DI closer to 0 indicates that a group contains both profitable and unprofitable corporations. We have also considered measuring correlation in within-group returns with a standard deviation of profit-to-turnover ratio (a ratio of reported after-tax accounting profit to sales).

To asses the performance of the attribute-based measures in replicating financial measures, Table 2 presents Pearson's correlation coefficients. The sample is limited to observations with non-missing financial data on subsidiaries, and is from 2002. As expected, the activity or location concentration is negatively correlated with the standard deviation of profit-to-turnover ratio, and is positively correlated with $D I$. The correlation coefficients are all significant at the $1 \%$ level except for the correlation between the standard deviation of returns with the location HHI and location CR3. The weaker correlation between the financial measure and location-based measures suggest some limitation of geographical diversity in capturing covariance in returns. Overall, strongly significant correlations are reassuring in basing analysis on the attribute-based measures.

\footnotetext{
${ }^{18} \mathrm{DI}$ is a statistic used to capture co-variance. Applications include co-movements in regional outputs, employment conditions across industries, business sentiments held by different corporation, among others.
} 


\section{B.3 Tax provisions}

Upon participation, the Japanese CFR allows parent to carry forward its own losses but not its subsidiaries' losses. A parent's carried forward losses would raise participation incentives but subsidiaries' carried forward losses would reduce participation incentives. To account for this difference in the treatment of prior losses, the model incorporates a measure of losses carried forward for parent and for subsidiary. A measure of parent's loss carry is a dummy variable that takes a value of 1 if a parent company reported a loss within past 7 years. ${ }^{19}$

The first measure of subsidiaries' loss carry is the share of wholly-owned subsidiaries reporting losses in all wholly-owned subsidiaries in a previous available sample. The second is the total amount of losses made by wholly-owned subsidiaries in a previous available sample. Once again, due to the limited coverage, estimation with subsidiary loss carry will be conducted in a smaller sample.

To predict the influence of small business concessions, we have considered the share of all small wholly-owned subsidiaries in all wholly-owned subsidiaries. We defined 'small' corporations as those with paid-up capital at or less than 100 million yen since a number of taxes and other public policies determines the eligibility small business concessions with this threshold.

\footnotetext{
${ }^{19}$ During the sample period, a tax amendment in 2004 extended the time limit from 5 to 7 years. The result was qualitatively the same when the dummy was defied using the 5-year cut off.
} 


\section{Empirical Analysis}

\section{A Preliminary examination}

As a preliminary analysis, Figure 2 presents Kaplan-Meier survivor functions covering 70 months since April 2002. Each panel presents a subsample with above and below the median of the measures of activity concentration. Clockwise from the top-left, the activity concentration measures are HHI, CR1, CR3 and CR2. The x-axis is the number of months since April 2002, and the y-axis is the (inverse of) probabilities of participation. Figure 2 thus summarises the likelihood of the participation in tax consolidation.

A visual inspection reveals several characteristics of the underlying data generation process that are relevant for modeling purposes. The estimated functions are step functions with a mass of participation taking place at discrete intervals. This is because groups switch tax regimes at the commencement of a new tax years (which correspond to accounting year). Since the participation occurs over 70 months, a survival analysis would capture the time dependence more readily than a discrete choice analysis with cross-section data at a given point in time. ${ }^{20}$ For instance, a baseline survivor function, if appropriately defined, can account for year effects. A survival analysis in addition can more readily incorporate time-varying factors, such as changes in financial situations that affect the tax advantages of consolidation. We thus consider implementing a survival analysis.

\footnotetext{
${ }^{20}$ If companies switch back to SAR, as they are legally allowed to, a survival analysis may not be suited in application. No company in the sample switched back to SAR
} 
One could fit a continuous time model with monthly interval, but to better account for the discrete nature of the process, we will fit discrete time models. An inspection also shows that a relatively large adoption at the outset and at the beginning of the 4 th year. This suggests that the time dependence is better captured with a flexible specification than ones that impose monotonicity. Lastly, the overall pattern appear similar with HHI or CR. HHI has an advantage in capturing the whole ranges of activities conducted within a group, since the statistic is constructed from the whole distribution rather than the top ones. ${ }^{21}$ We will hence base the main analysis on HHI.

On the whole the participation is not broad: Only $6.5 \%$ of the sample participate in tax consolidation by 70 months, or by the end of FY2008. Groups with more diverse activities, or less concentration measures, do appear to participate more actively. The difference is statistically significant according to the Cox proportional hazard model with the concentration measure as the only covariate. While this pattern is consistent with a hypothesis that groups with diverse activities tend to participate in tax consolidation, from this simple examination, we cannot be sure if the differential is in fact due to some confounding influences.

\footnotetext{
${ }^{21} \mathrm{CR} 1$ takes the value of 0.5 if group corporations are divided equally into two industries or a half is in one industry while the other half is in disparate industries. HHI takes the value of 0.5 for the former case and 0.3 for the latter case (assuming 10 companies in a group).
} 


\section{B Model}

Based on the considerations discussed above, the appropriate empirical model is a discrete time hazard model with a flexible functional form for duration dependence. We follow Jenkins (2005) in estimating a logistic hazard model.

$$
h\left(t, \mathbf{x}_{t}\right)=\left[1+\exp \left(-\alpha_{t}-\beta^{\prime} \mathbf{x}_{i t}\right)\right]^{-1}
$$

$h\left(t, \mathbf{x}_{i t}\right)$ is the discrete time hazard rate for $t^{\text {th }}$ year. $\mathbf{x}_{i t}$ is a vector of covariate. $\mathbf{x}_{i t}$ includes both time-invariant and time-variant covariate. Time-invariant covariate includes a measure of autocorrelation in parent $i$ 's return (AUTOCORR_P), a measure of variance in parent $i$ 's return (VARIANCE_P), industry dummies, and region dummies. Those dummy variables are included to control for industry and regional heterogeneity. Time-variant covariate include measures of within-group correlation in returns (HHI_IND, HHI_REG), numbers of subsidiaries (NUM), parent's loss carry (LOSCARRY_P), small business concession (SMALL), and remaining control variables.

The main specification employs the attribute-based measures of within-group correlation. An auxiliary analysis employs DI in a small sample. The number of subsidiaries is a count of all subsidiaries in group $i$ at year $t$. The model includes a square of the number of subsidiaries. The parent's loss carry is measured with a dummy variable that takes on the value of 1 if parent reported losses within past 7 years. The influence of small business 
concession is measured with the share of small wholly-owned subsidiaries in all whollyowned subsidiaries. A auxiliary analysis incorporates the measure of subsidiaries' losses carried forward (LOSCARRY_S). The time-variant controls are corporate age (AGE), log of asset (LNASSETS), and return to average equity (ROE). Appendix Table 1 lists variables definitions. $\beta$ is a vector of parameters on covariate to be estimated.

$\alpha_{t}$ is the logistic transformation of the baseline hazard, and captures the duration dependence as well as year effects. The year effects include the influence of amendments to tax law, such as the expiration of $2 \%$ surcharge on consolidated tax return for the first two years since the 2002 tax reform. ${ }^{22}$ We consider a functional form that is able to capture duration dependence flexibly: A piecewise constant with a dummy variable for each year. ${ }^{23}$

\section{Results}

\section{C.1 Sample 1}

We applied the sampling scheme described in Jenkins (2005) to reorganize the data and Table 3 reports summary statistics on the reorganized data for Sample 1 and 2. Table 4 presents main results based on Sample 1. Column 1 and 2 show respectively estimates with and without control variables in logistic regressions with duration dependence captured

\footnotetext{
${ }^{22}$ Given the delayed entries of corporations founded after 2002, or those became public since then, the separate identification of year effects and duration effects might appear possible. Since the sample of delayed entrants are small, the separate identification is difficult in practice.

${ }^{23} \mathrm{~A}$ forth order polynomial function of duration produced nearly identical estimates. We report the results from the piecewise constant specification since this specification allows for more flexibility in capturing underlying year dependence.
} 
with piecewise constant. The estimates on the key variables are qualitatively similar. The coefficients on activity concentration is negative and statistically significantly different from zero at the $1 \%$ level. The coefficients on location concentration is not statistically different from zero. Since the production process of manufacturers, such as auto producers, had became fragmented across firms and locations, it seems plausible that the diverse location of subsidiaries may not be a good measure of correlation in returns for those types of firms. Even for retail groups, relatively small diversity in regional economic growth in Japan over the sample period would lead to a weak relationship between covariance and geographic concentration. Recall that Table 2 shows a weaker correlation between the location-based measure and financial measures. The insignificant coefficient on the geographic concentration suggests that inability of the variable in capturing covariance.

The coefficients on the quadratic function of the number of subsidiaries imply a concave function and statistically significant. The coefficient on the share of small subsidiaries changes to an unexpected sign in the specification with controls but is not significantly significant. The coefficient on the autocorrelation are unexpectedly negative but are not statistically significant.

The coefficients on the measure of variability in return are positive, as expected, and are significantly different from zero at the $1 \%$ level. The coefficients on parent's carried forward losses are positive and statistically significantly different from zero at the $1 \%$ level. This suggests that a parent chose to consolidate so as to offset own losses. Overall, the results 
show that many of the tax motives being significant predictors of participation, even after controlling for various group characteristics.

The estimated duration dependence shows a similar pattern across the two columns. Relative to the initial year, the participation rate for all years are negative, and are significant for all years except the forth year which corresponds to 2005. The coefficients on 2004 (YEAR3) are also relatively low in magnitude. The results for 2004 and 2005 suggest that the expiration of a $2 \%$ surcharge on corporate tax during fiscal 2002 and 2003 has had some influence. The 2003 reform on R\&D tax credits increased the attractiveness of CFR so it might also have had some influence in a temporary resurgence in participation. The coefficients on age and return on average equity are positive but not significant. The coefficient on $\log$ asset is significant at the $1 \%$ level, indicating that size being a significant predictor of participation.

We have conducted a series of robustness checks. Column 3 presents results from a model with an alternative method for estimating discrete time model based on the complementary log-log transformation. The results are intact. Column 4 addresses a concern that the estimation results might suffer from an omitted variable bias. We estimated a random-effects logit model to allow for unobserved corporate-group specific effects. This model assumes that unobservable influences have a Normal distribution with mean zero. The coefficients on key covariate are qualitatively very similar. Overall the main conclusion remains intact.

The economic magnitudes of the key coefficients are of interests. The estimates from 
the random effect logit model (column 4) are generally larger in magnitude than those from the baseline logit model (column 2). While the former accounts for unobserved frailty, to be conservative, we consider both estimates in interpretation. The estimated hazard ratio for one standard deviation decrease in the business activity concentration is $1.49[=$ $\exp (-1.59 \times-0.25)]$ to -1.76 for the baseline model and the random effect model respectively. This means that the participation rate increases by 49 to $76 \%$ for a standard deviation decrease in activity concentration. ${ }^{24}$ The estimated hazard ratio for an additional subsidiary, evaluated at the mean number of subsidiaries (11 subsidiaries), is 1.022-1.039, indicating that the participation rate increases by $2-4 \%$ for an increase in the number of subsidiaries by 1. A group with a standard deviation higher variance is 1.7-2.1 times more likely to participate A parent with losses are 2.45-3.98 times more likely to participate. Overall, the results indicate significant influence of variance-covariance structures of corporate groups and parents' incentives to offset loss carry.

\section{C.2 Sensitivity analysis}

Are the results sensitive to the choice of measurements? To check the robustness of the results, we replaced different measurements one at a time to see if estimated coefficients vary significantly. The specification is the baseline logit model which requires less computation

\footnotetext{
${ }^{24}$ Consider a group with 12 members distributed across two industries. With an average HHI (roughly $0.5), 6$ members would be in each industry. One standard deviation increase in HHI (0.25) implies that, roughly, a split of 10 and 2 members across the two industries.
} 
time. Table 5 column 1 reproduces the estimates from Table 4 column 2.

The baseline analysis employed HHI to measure within-group correlation. CR is an alternative. Column 2 and 3 replace the HHI with the CR1 and CR3 respectively. The results are qualitatively the same as expected from strong correlations among these measures. The result from CR1 implies that 10 percentage points increase in concentration decreases participation by $17 \%$.

To estimate the degree of autocorrelation in parents' profitability across periods, the baseline analysis employed regressions of earning ratio on its lag and a constant. The estimates of partial autocorrelation coefficient would be overestimated if there is some underlying trend. To address this concern, we included in regressions on earning ratio firm-specific quadratic trends to obtain the measurements of autocorrelation, and report results in column 4 . We further included a second lag of earning ratio, and report result in column 5 . The results are intact for both cases. To see if the choice of profitability variable affected the results, the measure used in column 6 are estimated from regressions on ROE, rather than earning ratios, on its first lag and a constant. The result is qualitatively the same.

A reverse causality possibly confound the interpretation of the coefficient on the parent's loss carry. The restriction to carry forward losses in subsidiaries creates an incentive to shift losses to parent through transfer pricing. Thus, it may be the planned participation to CFR that raises the probability that parent companies report losses. To check this alternative explanation, we estimate a model with two dummy variables on parent's previous losses: 
One that takes on a value of 1 if a parent reported loss in the previous period, and another that takes on a value of 1 if a parent reported losses in past 2 to 7 years. If the direction of causation was reverse, the dummy on last-year losses, when we would expect the behavior to take place, to be significant while the dummy on older losses to be insignificant. Column (7) shows that both of these variables are significantly different from zero. Given the estimated influence of older losses, the possibility of transfer pricing does not explain away the result.

Column 8 considers an alternative measurement of small business concession by including a dummy variable that takes the value of 1 if a group includes at least one small whollyowned subsidiary. Reassuringly, the coefficient is still not significant with this specification change.

\section{C.3 Sample 2}

This section reports results from Sample 2, which omits observations with missing values on the financial variables. This deletion trims the sample size down to a third of Sample 1. The trimming has a disproportionate effects on participant sample, and the fraction of participation fell from $6.5 \%$ to $3.6 \%$. In interpreting changes in results, the reduction in sample size should be borne in mind.

Table 6, column 1 reproduces the baseline specification for comparison. For brevity the table reports coefficients on the main explanatory variables. The variance of parent return and the number of subsidiaries are still significant at the $1 \%$ level. Activity concentration and 
parent loss carry are no longer statistically significant. Since these variables are significant in the larger sample with the identical model, we suspect the loss of statistical power due to a smaller sample.

Column 2 replaces the attribute-based measures of correlations with a financial measure (DI). The model also incorporates the measure of losses carried forward by wholly-owned subsidiaries, defined as the number of wholly-owned subsidiaries with losses divided by the total number of wholly-owned subsidiaries The coefficient on DI is unexpectedly positive but not statistically significant. The coefficient on subsidiaries' loss carry is also unexpectedly positive but not statistically significant. Column 3 tries an alternative measure of covariance which is a standard deviation of profit-to-sales ratio computed over members of a corporate group, and finds similar results. Since the attribute-based measures are insignificant in this sample, perhaps due to the sample size, this is not strong evidence against the influence of covariance in returns.

Column 3 tries an alternative measure of subsidiaries' loss carry: The ratio of the absolute value of total losses generated by wholly-owned subsidiaries scaled by sales sizes of parent companies. The result similarly suggests subsidiaries' loss carry was not influential. This finding contrasts with survey on publicly traded companies which indicates the restriction on subsidiaries' loss carry being a major discouraging factor (Ohkura, 2004). Although our result suggests that survey respondents exaggerated the disadvantage of the loss carry restriction, caution is required in interpretation since the statistical power of the test may 
be weak in this small sample.

\section{Conclusion}

This paper examined participation to consolidated filing of corporate income taxes following the Japanese tax reform of 2002, and estimated a discrete-time hazard model on a sample of publicly traded companies over 2002-2007. The result showed that the probability of participation is higher for corporate groups with (1) high variance in profitability, (2) low within-group correlation in returns, and (3) parents with losses carried forward. Importantly, these characteristics give rise to incentives to engage in profit shifting when a corporate group must file separate tax returns for member corporations. We would hence expect that the consolidated filing would have contributed to efficiency of the Japanese tax system by reducing profit shifting motive for participating groups. The result however found some evidence of significant compliance costs by showing an association between group sizes and participation. We would hence expect that the overall gain in efficiency would have been limited since participants bore compliance costs and a significant number of non-participants remained to be taxed under a separate filing regime despite the availability of de facto legalization of profit shifting. 


\section{Appendix}

\section{A Proofs}

\section{Proof of Lemma 1}

Define $\underline{\pi}_{j}^{+} \equiv\left\{\pi_{j} \mid \pi_{j}>0\right\}$ and $\underline{\pi}_{j}^{-} \equiv\left\{\pi_{j} \mid \pi_{j}<0\right\}$. The tax payment under SFR is then

$$
\begin{aligned}
\sum_{j=1}^{J} \tau \max \left(\pi_{j}, 0\right) & =\sum_{\pi_{j} \in \underline{\pi}_{j}^{-}} \tau \max \left(\pi_{j}^{+}, 0\right) \\
& =\tau \max \left(\sum_{\pi_{j} \in \underline{\pi}_{j}^{+}} \pi_{j}^{+}, 0\right) .
\end{aligned}
$$

Tax payment under CFR is

$$
\tau \max \left(\sum_{j=1}^{J} \pi_{j}, 0\right)=\tau \max \left(\sum_{\pi_{j} \in \underline{\pi}_{j}^{+}} \pi_{j}^{+}+\sum_{\pi_{j} \in \underline{\pi}_{j}^{-}} \pi_{j}^{-}, 0\right) .
$$

Since $\sum_{\pi_{j} \in \underline{\pi}_{j}^{-}} \pi_{j}^{-}$is negative, or zero when $\underline{\pi}_{j}^{-}$is an empty set, it follows that $T^{S A R}(\underline{\psi}) \geqq$ $T^{C F R}(\underline{\psi})$ for $\forall \underline{\psi}$. Consequently $\Pi^{S A R}(\underline{\psi}) \leqq \Pi^{C F R}(\underline{\psi})$ for $\forall \underline{\psi}$.

\section{Proof of Lemma 2}

We show by contradiction that unless the proposition holds $\underline{\psi}^{*}$ cannot be the optimal choice under SAR. Note that $\Pi^{C F R}(\underline{\widetilde{\psi}})=\Pi^{C F R}\left(\underline{\psi}^{*}\right)$ since $\gamma=0$. From Lemma 1 we know $\Pi^{S A R}(\underline{\psi}) \leqq \Pi^{C F R}(\underline{\psi})$ for $\forall \underline{\psi}$.

Suppose that $\Pi^{S A R}\left(\underline{\psi}^{*}\right)<\Pi^{C F R}\left(\underline{\psi}^{*}\right)$. It must follow that the tax payment under SAR is larger than that under CFR.

$$
\tau \max \left(\sum_{\pi_{j} \in \underline{\pi}_{j}^{+}} \pi_{j}^{+}, 0\right)>\tau \max \left(\sum_{\pi_{j} \in \underline{\pi}_{j}^{+}} \pi_{j}^{+}+\sum_{\pi_{j} \in \underline{\pi}_{j}^{-}} \pi_{j}^{-}, 0\right)
$$


The strict inequality implies that there exists $\pi_{m}\left(\psi_{m}^{*}\right)=\rho_{m}+\psi_{m}^{*}<0$ and $\pi_{n}\left(\psi_{m}^{*}\right)=$ $\rho_{n}+\psi_{n}^{*}>0$. Now consider an alternative choice $\underline{\hat{\psi}}$ which has identical elements as in $\underline{\psi}^{*}$ except $\widehat{\psi}_{m}=\psi_{m}^{*}+\varepsilon$ for $m^{\text {th }}$ company and $\widehat{\psi}_{n}=\psi_{n}^{*}-\varepsilon$ for $n^{\text {th }}$ company. $\varepsilon$ is an arbitrarily small positive number. The tax base under SAR is

$$
\sum_{\pi_{j} \in \underline{\pi}_{j}^{+}} \pi_{j}^{+}\left(\widehat{\psi}_{j}\right)=\sum_{\pi_{j} \in \underline{\underline{\pi}}_{j}^{+}} \pi_{j}^{+}\left(\psi_{j}^{*}\right)-\varepsilon<\sum_{\pi_{j} \in \underline{\pi}_{j}^{+}} \pi_{j}^{+}\left(\psi_{j}^{*}\right) .
$$

Since the tax base with $\underline{\widehat{\psi}}$ is smaller than that under $\underline{\psi}^{*}, \underline{\hat{\psi}}$ must generate a higher profit. This contradicts the assumption that $\underline{\psi}^{*}$ maximizes profit. By exhaustion, it thus must be the case that $\Pi^{S A R}\left(\underline{\psi}^{*}\right)=\Pi^{C F R}\left(\underline{\psi}^{*}\right)$.

\section{Proof of Proposition 1}

From Lemma 1 we have $\Pi^{S A R}(\underline{\widetilde{\psi}}) \leqq \Pi^{C F R}(\underline{\widetilde{\psi}})$. Note that if $\gamma$ is very large, so that profit shifting is prohibitively costly, the firm will choose $\widetilde{\psi}$ under SAR. If $\gamma$ is sufficiently small the firm will choose $\underline{\psi}$ so that $\Pi^{S A R}(\underline{\widetilde{\psi}})<\Pi^{S A R}\left(\underline{\psi}^{*}\right) \leqq \Pi^{C F R}(\underline{\widetilde{\psi}})$. The second inequality follows since we know from Lemma 2 that when $\gamma=0, \Pi^{S A R}\left(\underline{\psi}^{*}\right)=\Pi^{C F R}(\underline{\widetilde{\psi}})$. It follows that $\Pi^{C F R}(\underline{\widetilde{\psi}})-\Pi^{S A R}(\underline{\widetilde{\psi}})$. is the maximum tax savings.

\section{B Specifications in the simulation}

This section provides specification details of the simulation analysis discussed in the main text.

\section{Baseline simulation}


In the baseline simulation, we generated random values $\left(y_{i j}\right)$ representing before-tax returns of companies belonging to corporate groups. $i$ denotes $i^{\text {th }}$ corporate group. $j$ denotes $j^{\text {th }}$ company in $i^{\text {th }}$ corporate group. The following table summarizes the base parameter values.

\begin{tabular}{ll}
\hline \hline Parameters & Specification \\
\hline Number of samples/corporate groups & 10,000 \\
Number of group members & 20 \\
Distribution & Normal, independently distributed \\
Mean & 100 \\
Standard deviation & 100 \\
Tax rate & $30 \%$ \\
\hline
\end{tabular}

We then computed after-tax returns and tax savings by applying the following formula to the generated data.

\begin{tabular}{ll}
\hline \hline Outcomes & Formula \\
\hline After-tax group return under CFR & $\sum_{j=1}^{J} y_{i j}-\tau \max \left(\sum_{j=1}^{J} y_{i j}, 0\right)$ \\
After-tax group return under SAR & $\sum_{j=1}^{J} y_{i j}-\sum_{j=1}^{J} \tau \max \left(y_{i j}, 0\right)$ \\
Tax savings from adopting CFR $(D)$ & $\sum_{j=1}^{J} \tau \max \left(y_{i j}, 0\right)-\tau \max \left(\sum_{j=1}^{J} y_{i j}, 0\right)$ \\
\hline
\end{tabular}

\section{Within-group correlation}

To allow for within-group correlation in the static setting, we modeled within group 
correlation as companies belonging to $i^{\text {th }}$ group sharing a common shock $\left(y_{i 0}\right)$, and generated random samples using the following formula

$$
y_{i j}=100+\rho y_{i 0}+\left(1-\rho^{2}\right)^{0.5} e_{i j}
$$

$j \in[1, J]$ denotes $j^{t h}$ company in group $i . y_{0 i}$ and $e_{i j}$ are independently distributed, and are generated from $N(0,100) . \rho \in[0,1]$ represents the degree of intra-group correlation arising from sharing a common group-wide shock. $e_{i j}$ is multiplied by a function of $\rho$ so that the standard deviation of $y_{j i}$ is kept constant regardless of the degree of correlation.

\section{Autocorrelation}

To allow for autocorrelation in return, we generated a random sample using the following formula.

$$
y_{i, j, t}=(1-\alpha) \times 100+\alpha y_{i, j, t-1}+\left(1-\alpha^{2}\right)^{0.5} e_{i, j, t}
$$

$y_{i, j, t-1}$ is a before-tax return from the previous period. $e_{i, j, t}$ is a random component distributed as $N(0,100) \cdot y_{i, j, t-1}$ and $e_{i, j, t}$ are independently distributed. $\alpha \in(0,1)$ represents the degree of autocorrelation. The constant term, $(1-\alpha) \times 100$, ensures that the expected value of $y_{i, j, t}$ remains constant across different values of $\alpha$. The coefficient on $e_{i, j, t}$ ensures that the variance of $y_{j, t, i}$ remains constant across different values of $\alpha . t$ represents the time period. The simulation generated 4 million data points, consisting of 20 period data for 10,000 groups, each consisting of 20 members.

SAR with carry forward is computed from the following formula. 


$$
\sum y_{j, t, i}-\sum \tau \max \left(y_{j, t, i}-L C F_{j, t, i}, 0\right)
$$

where $L C F_{j, t, i}$ represents the deduction from accumulated losses. The table below summarises formula used to compute the deduction amount. We report tax savings when the firm adopts CFR at the last period $(t=20)$.

\begin{tabular}{ll}
\hline \hline Expiration & Formula for $L C F_{j, t, i}$ \\
\hline 1 year & $\min \left(y_{j, t-1, i}, 0\right)$ \\
No expiration & $\min \left(y_{j, t-1, i}+\widetilde{y}_{j, t-2, i}, 0\right)$ where $\widetilde{y}_{j, t-k, i}=\min \left(y_{j, t-k, i}+\widetilde{y}_{j, t-k-1, i}, 0\right)$ \\
\hline & and $\widetilde{y}_{j, 0, i}=\widetilde{y}_{j,-1, i}=0$ \\
\hline
\end{tabular}

\section{References}

Buettner, Thiess; Nadine Riedel and Marco Runkel. 2011. "Strategic Consolidation Under Formula Apportionment." National Tax Journal, 64(2), pp. 225-254.

Cummings, Jasper L. Jr. 2011. Consolidating Foreign Affiliates." Florida Tax Review, 143(11), pp. 163-195.

Devereux, Michael P. and Simon Loretz. 2008. "The Effects of EU Formula Apportionment on Corporate Tax Revenues." Fiscal Studies, 29(1), pp. 1-33.

Eden, Lorraine; Luis F. Juarez Valdez and Dan Li. 2005. Talk softly but carry a big stick: transfer pricing penalties and the market valuation of Japanese multinationals in the United States." Journal of International Business Studies, 36(4), pp 398-414.

Eichner, Thomas and Marco Runkel. 2011. "Corporate Income Taxation of Multinationals in a General Equilibrium Model." Journal of Public Economics, 95(7-8), pp. 723-733.

Gordon, Roger H. and James R. Hines. 2002. International Taxation. In: Auerbach, A.J. \& Feldstein, M. (eds.) Handbook of Public Economics. Amsterdam: Elsevier. 
Gresik, Thomas. 2012. "Canadian Tax Policy: A Hybrid Formula Apportionment and Separate Accounting Approach." Mimeo.

Hamilton, James D. 2004. Time Series Analysis. Princeton, NJ: Princeton University Press.

Haufler, Andreas and Mohammed Mardan. 2012. "Tax Competition and Risk-taking under Cross-border Loss Offset." unpublished manuscript.

Jenkins, Stephen P. 2005. Survival Analysis. Unpublished manuscript, Institute for Social and Economic Research, University of Essex, Colchester, U.K.

John, Kose and Eli Ofek. 1995." Asset sales and increase in focus." Journal of Financial Economics, 37(1), pp. 105-126.

Kalamov, Zarko and Marco Runkel. 2012. "The Implications of Cross-border Loss-Offset: Should the EU Really Implement It?" Mimeo.

Mintz, Jack M. 2004. "Corporate Tax Harmonization in Europe: It's All About Compliance." International Tax and Public Finance, 11(2), pp. 221-34.

Mintz, Jack M. and Michael Smart. 2004. "Income Shifting, Investment, and Tax Competition: Theory and Evidence from Provincial Taxation in Canada." Journal of Public Economics, 88(6), pp. 1149-1168.

Ohkura, Yujiro. 2004. "A Study from the Accounting Point of View on the Adoption Tendency of the Consolidated Tax System: From a Research of Listed Companies on the First Section Market of the Tokyo Stock Exchange." Kansai University Review of Business and Commerce, 6, pp. 21-42. (in Japanese)

Onji, Kazuki. 2011. "Tax Consolidation and the Structure of Corporate Groups: Evidence from the Japanese Tax Reform of 2002." Asia Pacific Economic Papers, No. 394.

Onji, Kazuki and David Vera. 2010. "Tax Law Asymmetries and Income Shifting: Evidence from Japanese Capital Keiretsu." B.E. Journal of Economic Analysis \& Policy (Advances), 10(1).

Oestreicher, Andreas and Reinald Koch. 2010. "The Determinants of Opting for the German Group Taxation Regime with Regard to Taxes on Corporate Profits." Review of Managerial Science, 4(2), pp.119-147. 
Figure 1

Simulation on factors that affect tax savings in adopting CFR

Panel A: Expected return

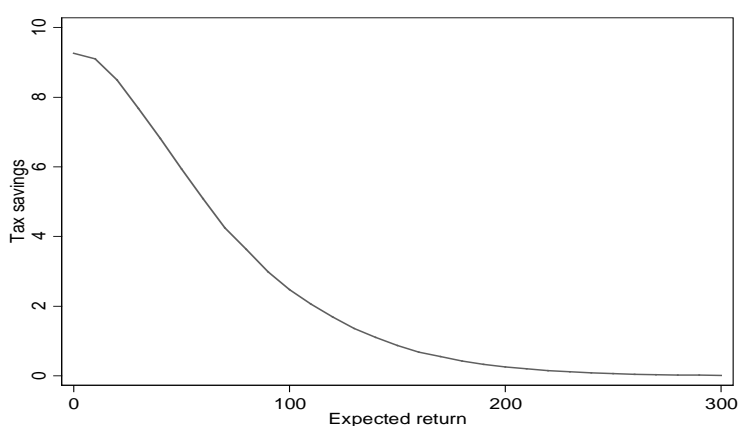

Panel C: Group size

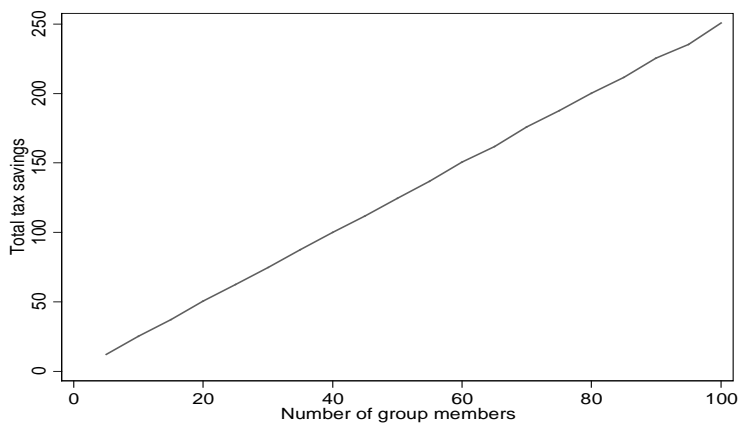

Panel E: Co-movement in returns

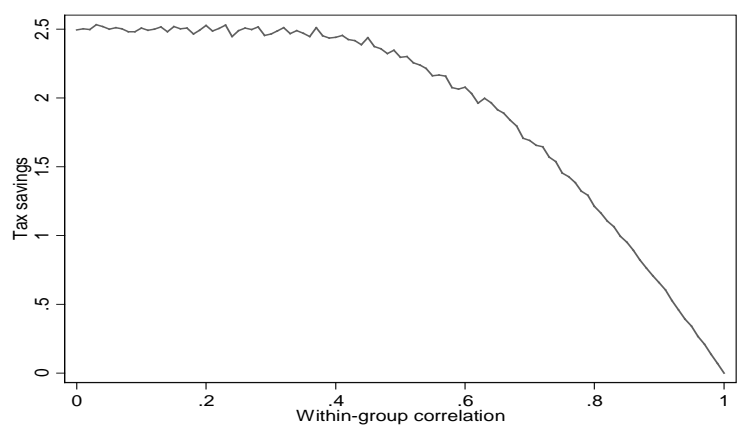

Panel B: Variability in return

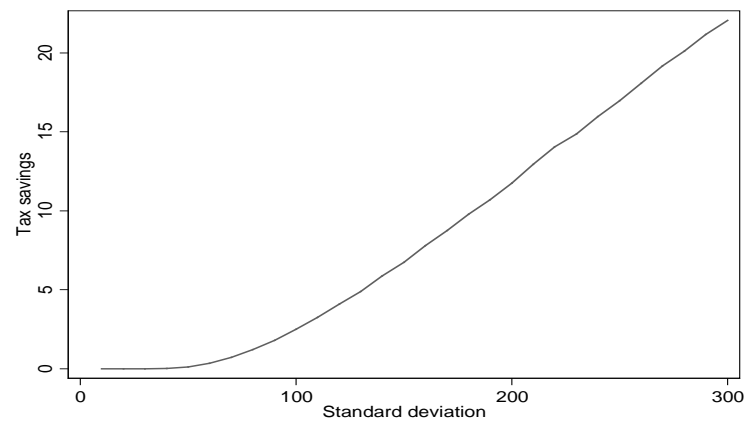

Panel D: Distribution by group size

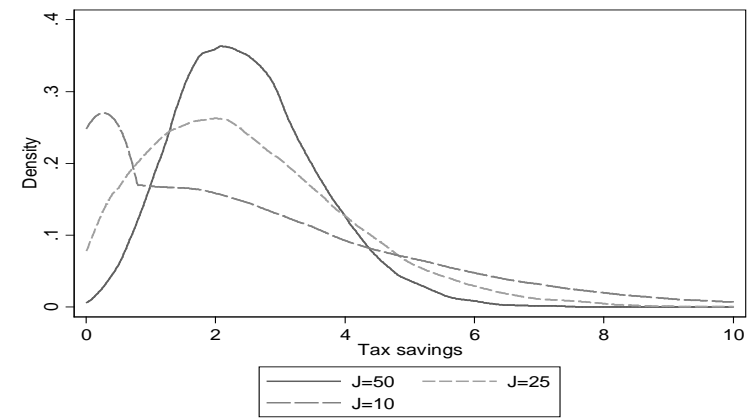

Panel F: Autocorrelation

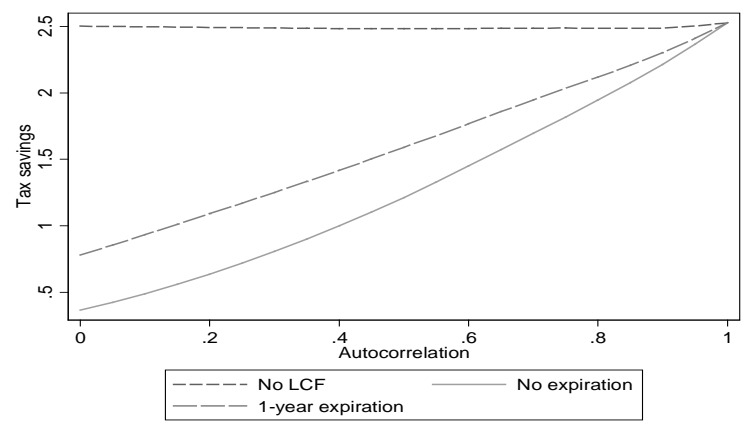


Figure 2

Kaplan-Meier survivor functions
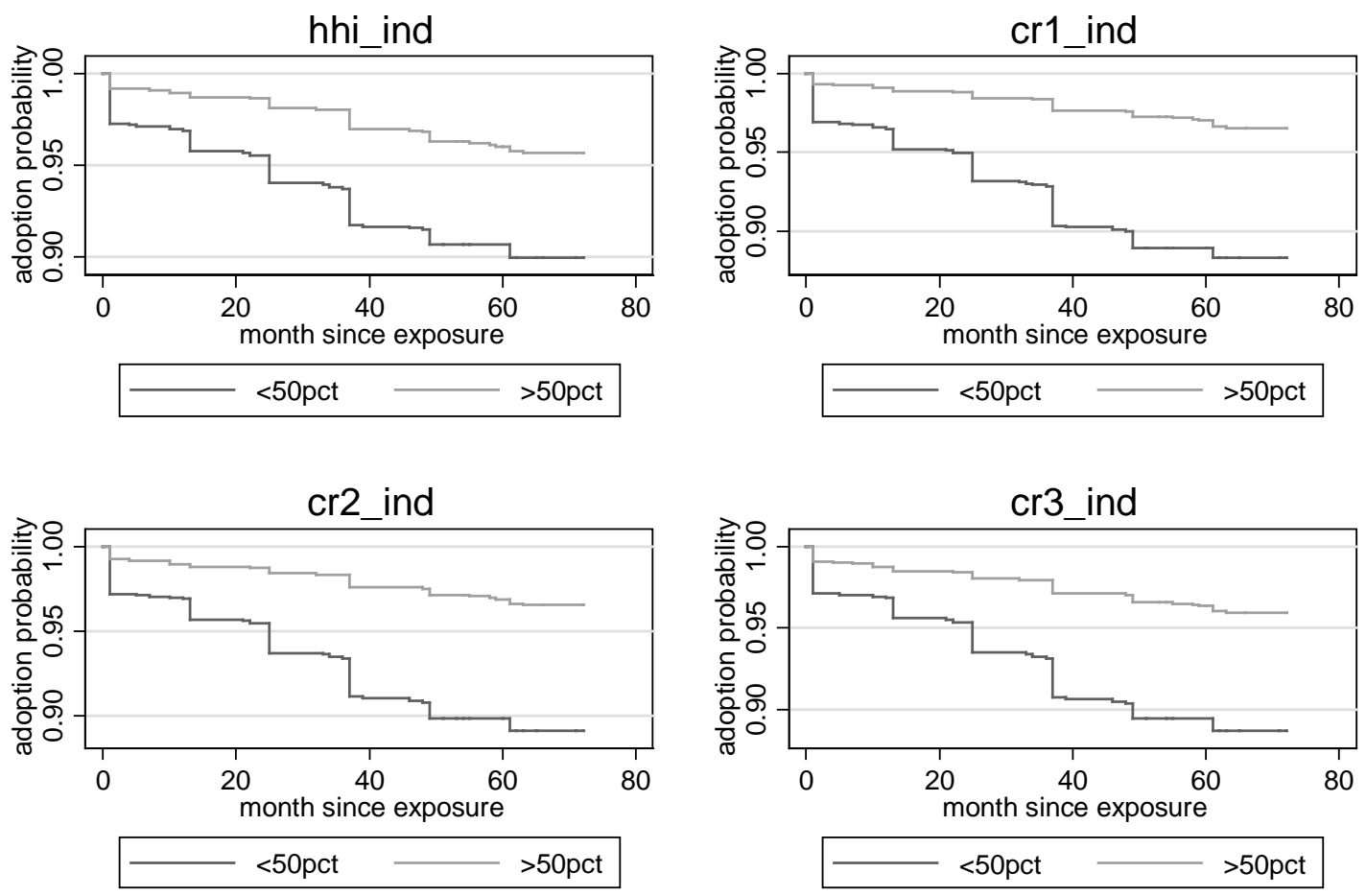
Table 2

Correlation matrix of covariance measures

\begin{tabular}{|c|c|c|c|c|c|c|c|}
\hline & CR1_IND & CR1_REG & CR3_IND & CR3_REG & HHI_IND & HHI_REG & DI \\
\hline CR1_REG & $\begin{array}{c}0.35 \\
(0.00) \\
\end{array}$ & & & & & & \\
\hline CR3_IND & $\begin{array}{c}0.54 \\
(0.00)\end{array}$ & $\begin{array}{c}0.42 \\
(0.00)\end{array}$ & & & & & \\
\hline CR3_REG & $\begin{array}{c}0.27 \\
(0.00)\end{array}$ & $\begin{array}{c}0.44 \\
(0.00)\end{array}$ & $\begin{array}{c}0.42 \\
(0.00)\end{array}$ & & & & \\
\hline HHI_IND & $\begin{array}{c}0.82 \\
(0.00) \\
\end{array}$ & $\begin{array}{c}0.21 \\
(0.00)\end{array}$ & $\begin{array}{c}0.59 \\
(0.00)\end{array}$ & $\begin{array}{c}0.14 \\
(0.00) \\
\end{array}$ & & & \\
\hline HHI_REG & $\begin{array}{c}0.22 \\
(0.00) \\
\end{array}$ & $\begin{array}{r}0.86 \\
(0.00) \\
\end{array}$ & $\begin{array}{r}0.27 \\
(0.00) \\
\end{array}$ & $\begin{array}{c}0.52 \\
(0.00) \\
\end{array}$ & $\begin{array}{c}0.08 \\
(0.00) \\
\end{array}$ & & \\
\hline DI & $\begin{array}{c}0.12 \\
(0.00) \\
\end{array}$ & $\begin{array}{c}0.09 \\
(0.00) \\
\end{array}$ & $\begin{array}{c}0.10 \\
(0.00) \\
\end{array}$ & $\begin{array}{c}0.07 \\
(0.01) \\
\end{array}$ & $\begin{array}{c}0.09 \\
(0.00) \\
\end{array}$ & $\begin{array}{r}0.08 \\
(0.00) \\
\end{array}$ & \\
\hline STDPROFIT & $\begin{array}{l}-0.08 \\
(0.00) \\
\end{array}$ & $\begin{array}{c}-0.08 \\
(0.00) \\
\end{array}$ & $\begin{array}{l}-0.14 \\
(0.00) \\
\end{array}$ & $\begin{array}{l}-0.04 \\
(0.14) \\
\end{array}$ & $\begin{array}{c}-0.09 \\
(0.00) \\
\end{array}$ & $\begin{array}{l}-0.03 \\
(0.24) \\
\end{array}$ & $\begin{array}{l}-0.15 \\
(0.00) \\
\end{array}$ \\
\hline
\end{tabular}

Notes: P-values are reported in parentheses. Values are computed from 1,373 observations in the 2002 sample. 
Table 3

Summary statistics

\begin{tabular}{|c|c|c|c|c|}
\hline & \multicolumn{2}{|c|}{ SAMPLE1 } & \multicolumn{2}{|c|}{ SAMPLE2 } \\
\hline & mean & s.d. & mean & s.d. \\
\hline PARTICIPATION & 0.013 & 0.114 & 0.009 & 0.094 \\
\hline HHI_IND & 0.489 & 0.252 & 0.503 & 0.252 \\
\hline HHI_REG & 0.604 & 0.296 & 0.625 & 0.287 \\
\hline NUM & 11.3 & 17.2 & 8.5 & 11.5 \\
\hline SMALL & 0.539 & 0.334 & 0.564 & 0.345 \\
\hline AUTOCORR_P & 0.507 & 0.296 & 0.513 & 0.288 \\
\hline VARIANCE_P & 3.5 & 2.6 & 3.3 & 2.3 \\
\hline LOSSCARRY_P & 0.571 & 0.495 & 0.569 & 0.495 \\
\hline AGE & 50.5 & 22.1 & 52.2 & 20.4 \\
\hline ROE & 3.5 & 14.5 & 3.8 & 12.8 \\
\hline LNASSETS & 10.6 & 1.5 & 10.4 & 1.3 \\
\hline DI & & & 0.635 & 0.340 \\
\hline LOSSCARRY_S1 & & & 0.213 & 0.273 \\
\hline LOSSCARRY_S2 & & & 0.007 & 0.029 \\
\hline STDEVPROFIT & & & 0.304 & 2.493 \\
\hline Number of observations & 13,807 & & 4,608 & \\
\hline Number of groups & 2,782 & & 1,496 & \\
\hline Number of CFR participants & 181 & $(6.5 \%)$ & 54 & $(3.6 \%)$ \\
\hline Mean participatin year of participants & 2004.2 & & 2004.4 & \\
\hline
\end{tabular}


Table 4: Discrete-time hazard model estimates

\begin{tabular}{|c|c|c|c|c|}
\hline VARIABLES & $\begin{array}{c}(1) \\
\text { LOGIT } \\
\text { BASE } \\
\end{array}$ & $\begin{array}{c}(2) \\
\text { LOGIT } \\
+ \text { CONTROL }\end{array}$ & $\begin{array}{c}(3) \\
\text { CLOGLOG } \\
+ \text { CONTROL } \\
\end{array}$ & $\begin{array}{c}(4) \\
\text { RELOGIT } \\
+ \text { CONTROL }\end{array}$ \\
\hline HHI_IND & $\begin{array}{c}-2.027^{* *} \\
(0.437)\end{array}$ & $\begin{array}{c}-1.590 * * \\
(0.462)\end{array}$ & $\begin{array}{c}-1.574 * * \\
(0.456)\end{array}$ & $\begin{array}{c}-2.252^{* *} \\
(0.778)\end{array}$ \\
\hline HHI_REG & $\begin{array}{l}-0.202 \\
(0.315)\end{array}$ & $\begin{array}{c}0.063 \\
(0.331)\end{array}$ & $\begin{array}{c}0.068 \\
(0.325)\end{array}$ & $\begin{array}{c}0.048 \\
(0.497)\end{array}$ \\
\hline NUM & $\begin{array}{l}0.032 * * \\
(0.006)\end{array}$ & $\begin{array}{l}0.023^{* *} \\
(0.007)\end{array}$ & $\begin{array}{l}0.022 * * \\
(0.007)\end{array}$ & $\begin{array}{l}0.041^{*} \\
(0.016)\end{array}$ \\
\hline NUMSQ & $\begin{array}{c}-0.092^{* *} \\
(0.029)\end{array}$ & $\begin{array}{l}-0.066^{*} \\
(0.033)\end{array}$ & $\begin{array}{l}-0.065^{*} \\
(0.030)\end{array}$ & $\begin{array}{r}-0.117+ \\
(0.067)\end{array}$ \\
\hline SMALL & $\begin{array}{l}-0.023 \\
(0.266)\end{array}$ & $\begin{array}{c}0.110 \\
(0.267)\end{array}$ & $\begin{array}{c}0.111 \\
(0.262)\end{array}$ & $\begin{array}{c}0.200 \\
(0.400)\end{array}$ \\
\hline AUTOCORR_P & $\begin{array}{l}-0.191 \\
(0.310)\end{array}$ & $\begin{array}{l}-0.068 \\
(0.333)\end{array}$ & $\begin{array}{l}-0.073 \\
(0.326)\end{array}$ & $\begin{array}{c}0.023 \\
(0.456)\end{array}$ \\
\hline VARIANCE_P & $\begin{array}{l}0.143^{* *} \\
(0.022)\end{array}$ & $\begin{array}{l}0.194^{* *} \\
(0.030)\end{array}$ & $\begin{array}{l}0.190 * * \\
(0.029)\end{array}$ & $\begin{array}{l}0.283^{* *} \\
(0.074)\end{array}$ \\
\hline LOSSCARRY_P & $\begin{array}{l}1.038 * * \\
(0.212)\end{array}$ & $\begin{array}{l}0.896^{* *} \\
(0.215)\end{array}$ & $\begin{array}{l}0.887 * * \\
(0.214)\end{array}$ & $\begin{array}{l}1.382 * * \\
(0.422)\end{array}$ \\
\hline AGE & & $\begin{array}{c}0.003 \\
(0.004)\end{array}$ & $\begin{array}{c}0.003 \\
(0.004)\end{array}$ & $\begin{array}{c}0.004 \\
(0.007)\end{array}$ \\
\hline ROE & & $\begin{array}{c}0.000 \\
(0.004)\end{array}$ & $\begin{array}{c}0.000 \\
(0.004)\end{array}$ & $\begin{array}{c}0.004 \\
(0.006)\end{array}$ \\
\hline LNASSETS & & $\begin{array}{l}0.216^{* *} \\
(0.081)\end{array}$ & $\begin{array}{l}0.214^{* *} \\
(0.079)\end{array}$ & $\begin{array}{l}0.297 * \\
(0.127)\end{array}$ \\
\hline YEAR 2 & $\begin{array}{c}-0.752^{* *} \\
(0.268)\end{array}$ & $\begin{array}{c}-0.760 * * \\
(0.272)\end{array}$ & $\begin{array}{c}-0.731^{* *} \\
(0.269)\end{array}$ & $\begin{array}{l}-0.548 \\
(0.365)\end{array}$ \\
\hline YEAR 3 & $\begin{array}{l}-0.501^{*} \\
(0.245)\end{array}$ & $\begin{array}{r}-0.475^{+} \\
(0.250)\end{array}$ & $\begin{array}{l}-0.458+ \\
(0.245)\end{array}$ & $\begin{array}{l}-0.035 \\
(0.433)\end{array}$ \\
\hline YEAR 4 & $\begin{array}{l}-0.111 \\
(0.225)\end{array}$ & $\begin{array}{l}-0.095 \\
(0.231)\end{array}$ & $\begin{array}{l}-0.094 \\
(0.226)\end{array}$ & $\begin{array}{c}0.617 \\
(0.556)\end{array}$ \\
\hline YEAR 5 & $\begin{array}{l}-0.633^{*} \\
(0.248)\end{array}$ & $\begin{array}{l}-0.598^{*} \\
(0.250)\end{array}$ & $\begin{array}{l}-0.586^{*} \\
(0.244)\end{array}$ & $\begin{array}{c}0.094 \\
(0.562)\end{array}$ \\
\hline YEAR 6 & $\begin{array}{c}-1.046^{* *} \\
(0.289)\end{array}$ & $\begin{array}{c}-1.002 * * \\
(0.292)\end{array}$ & $\begin{array}{c}-0.985^{* *} \\
(0.287)\end{array}$ & $\begin{array}{l}-0.161 \\
(0.658)\end{array}$ \\
\hline CONSTANT & $\begin{array}{l}-4.584^{* *} \\
(0.440)\end{array}$ & $\begin{array}{c}-8.289 * * \\
(1.530)\end{array}$ & $\begin{array}{c}-8.258^{* *} \\
(1.511)\end{array}$ & $\begin{array}{c}-12.486^{* *} \\
(3.393)\end{array}$ \\
\hline Observations & 13,807 & 13,807 & 13,807 & 13,807 \\
\hline $\begin{array}{l}\text { Log likelihood } \\
\text { pseudo-R-squared }\end{array}$ & $\begin{array}{c}-857.5 \\
0.111\end{array}$ & $\begin{array}{c}-837.2 \\
0.132\end{array}$ & -837.2 & $\begin{array}{c}-834.6 \\
-\end{array}$ \\
\hline
\end{tabular}

Robust standard errors in parentheses for column 1-3. Standard errors based on the observed information matrix in parentheses for column 4 . Regressions with controls include region and industry dummies. ${ }^{* *} \mathrm{p}<0.01,{ }^{*} \mathrm{p}<0.05,+\mathrm{p}<0.1$ 
Table 5 Robustness checks

\begin{tabular}{|c|c|c|c|c|c|c|c|c|}
\hline VARIABLES & $\begin{array}{c}(1) \\
\text { LOGIT } \\
\text { Baseline }\end{array}$ & $\begin{array}{c}(2) \\
\text { LOGIT } \\
\text { Rho=CR1 }\end{array}$ & $\begin{array}{c}(3) \\
\text { LOGIT } \\
\text { Rho=CR3 }\end{array}$ & $\begin{array}{c}(4) \\
\text { LOGIT } \\
\text { Delta2 } \\
\end{array}$ & $\begin{array}{c}(5) \\
\text { LOGIT } \\
\text { Delta3 } \\
\end{array}$ & $\begin{array}{c}(6) \\
\text { LOGIT } \\
\text { Delta4 } \\
\end{array}$ & $\begin{array}{c}(7) \\
\text { LOGIT } \\
\text { LCF2 } \\
\end{array}$ & $\begin{array}{c}(8) \\
\text { LOGIT } \\
\text { SBC2 } \\
\end{array}$ \\
\hline HHI_IND & $\begin{array}{c}-1.590^{* *} \\
(0.462)\end{array}$ & & & $\begin{array}{c}-1.640^{* *} \\
(0.460)\end{array}$ & $\begin{array}{c}-1.667 * * \\
(0.459)\end{array}$ & $\begin{array}{c}-1.555^{* *} \\
(0.460)\end{array}$ & $\begin{array}{c}-1.579 * * \\
(0.464)\end{array}$ & $\begin{array}{c}-1.511^{* *} \\
(0.462)\end{array}$ \\
\hline HHI_REG & $\begin{array}{c}0.063 \\
(0.331)\end{array}$ & & & $\begin{array}{c}0.082 \\
(0.329)\end{array}$ & $\begin{array}{c}0.120 \\
(0.329)\end{array}$ & $\begin{array}{c}0.176 \\
(0.323)\end{array}$ & $\begin{array}{c}0.024 \\
(0.329)\end{array}$ & $\begin{array}{c}0.096 \\
(0.333)\end{array}$ \\
\hline NUM & $\begin{array}{l}0.023^{* *} \\
(0.007)\end{array}$ & $\begin{array}{l}0.016^{*} \\
(0.007)\end{array}$ & $\begin{array}{l}0.017+ \\
(0.009)\end{array}$ & $\begin{array}{l}0.024^{* *} \\
(0.008)\end{array}$ & $\begin{array}{l}0.026^{* *} \\
(0.008)\end{array}$ & $\begin{array}{l}0.028^{* *} \\
(0.008)\end{array}$ & $\begin{array}{l}0.021^{* *} \\
(0.008)\end{array}$ & $\begin{array}{l}0.022^{* *} \\
(0.007)\end{array}$ \\
\hline NUMSQ & $\begin{array}{l}-0.066^{*} \\
(0.033)\end{array}$ & $\begin{array}{l}-0.035 \\
(0.031)\end{array}$ & $\begin{array}{l}-0.039 \\
(0.036)\end{array}$ & $\begin{array}{l}-0.070^{*} \\
(0.033)\end{array}$ & $\begin{array}{l}-0.076^{*} \\
(0.033)\end{array}$ & $\begin{array}{l}-0.085^{*} \\
(0.034)\end{array}$ & $\begin{array}{l}-0.063+ \\
(0.034)\end{array}$ & $\begin{array}{c}-0.064+ \\
(0.033)\end{array}$ \\
\hline SMALL & $\begin{array}{c}0.110 \\
(0.267)\end{array}$ & $\begin{array}{c}0.114 \\
(0.284)\end{array}$ & $\begin{array}{c}0.095 \\
(0.265)\end{array}$ & $\begin{array}{c}0.051 \\
(0.261)\end{array}$ & $\begin{array}{c}0.045 \\
(0.262)\end{array}$ & $\begin{array}{c}0.071 \\
(0.258)\end{array}$ & $\begin{array}{c}0.134 \\
(0.268)\end{array}$ & \\
\hline AUTOCORR_P & $\begin{array}{l}-0.068 \\
(0.333)\end{array}$ & $\begin{array}{l}-0.044 \\
(0.329)\end{array}$ & $\begin{array}{l}-0.026 \\
(0.336)\end{array}$ & & & & $\begin{array}{l}-0.093 \\
(0.329)\end{array}$ & $\begin{array}{l}-0.066 \\
(0.332)\end{array}$ \\
\hline VARIANCE_P & $\begin{array}{l}0.194^{* *} \\
(0.030)\end{array}$ & $\begin{array}{l}0.205^{* *} \\
(0.030)\end{array}$ & $\begin{array}{l}0.201^{* *} \\
(0.030)\end{array}$ & & & & $\begin{array}{l}0.182^{* *} \\
(0.030)\end{array}$ & $\begin{array}{l}0.196^{* *} \\
(0.030)\end{array}$ \\
\hline LOSSCARRY_P & $\begin{array}{l}0.896^{* *} \\
(0.215)\end{array}$ & $\begin{array}{l}0.881^{* *} \\
(0.213)\end{array}$ & $\begin{array}{l}0.900^{* *} \\
(0.217)\end{array}$ & $\begin{array}{l}0.904^{* *} \\
(0.211)\end{array}$ & $\begin{array}{l}0.887^{* *} \\
(0.213)\end{array}$ & $\begin{array}{l}0.858^{* *} \\
(0.220)\end{array}$ & & $\begin{array}{l}0.889^{* *} \\
(0.215)\end{array}$ \\
\hline CR1_IND & & $\begin{array}{c}-1.879 * * \\
(0.655)\end{array}$ & & & & & & \\
\hline CR1_REG & & $\begin{array}{l}-0.236 \\
(0.329)\end{array}$ & & & & & & \\
\hline CR3_IND & & & $\begin{array}{c}-1.160^{* *} \\
(0.376)\end{array}$ & & & & & \\
\hline CR3_REG & & & $\begin{array}{c}0.381 \\
(0.342)\end{array}$ & & & & & \\
\hline AUTOCORR_P_2 & & & & $\begin{array}{l}-0.332 \\
(0.386)\end{array}$ & & & & \\
\hline VARIANCE_P_2 & & & & $\begin{array}{l}0.199 * * \\
(0.035)\end{array}$ & & & & \\
\hline AUTOCORR_P_3a & & & & & $\begin{array}{l}-0.298 \\
(0.235)\end{array}$ & & & \\
\hline AUTOCORR_P_3b & & & & & $\begin{array}{l}-0.179 \\
(0.214)\end{array}$ & & & \\
\hline VARIANCE_P_3 & & & & & $\begin{array}{l}0.201^{* *} \\
(0.035)\end{array}$ & & & \\
\hline AUTOCORR_P_4 & & & & & & $\begin{array}{c}0.136 \\
(0.262)\end{array}$ & & \\
\hline VARIANCE_P_4 & & & & & & $\begin{array}{l}0.067 * * \\
(0.010)\end{array}$ & & \\
\hline LOSSCARRY_P_1 & & & & & & & $\begin{array}{c}0.650^{* *} \\
(0.181)\end{array}$ & \\
\hline LOSSCARRY_P_2-' & & & & & & & $\begin{array}{l}0.944^{* *} \\
(0.197)\end{array}$ & \\
\hline SMALL2 & & & & & & & & $\begin{array}{c}0.326 \\
(0.328)\end{array}$ \\
\hline Constant & $\begin{array}{c}-8.289 * * \\
(1.530)\end{array}$ & $\begin{array}{c}-8.307^{* *} \\
(1.445)\end{array}$ & $\begin{array}{c}-8.527 * * \\
(1.563)\end{array}$ & $\begin{array}{c}-7.627 * * \\
(1.485)\end{array}$ & $\begin{array}{c}-7.562 * * \\
(1.492)\end{array}$ & $\begin{array}{c}-7.936^{* *} \\
(1.491)\end{array}$ & $\begin{array}{c}-8.852 * * \\
(1.527)\end{array}$ & $\begin{array}{c}-8.539 * * \\
(1.577)\end{array}$ \\
\hline Observations & 13,807 & 13,807 & 13,807 & 13,807 & 13,807 & 13,807 & 13,807 & 13,807 \\
\hline Il & -837.2 & -834.3 & -837.8 & -840.5 & -839.5 & -834.1 & -825.2 & -836.7 \\
\hline r2_p & 0.132 & 0.135 & 0.131 & 0.128 & 0.129 & 0.135 & 0.144 & 0.132 \\
\hline
\end{tabular}

Robust standard errors in parentheses. All egressions include region and industry dummies. ${ }^{* *} \mathrm{p}<0.01,{ }^{*} \mathrm{p}<0.05,+\mathrm{p}<0.1$ 
Table 6

Smaller sample with non-missing financial information

(1)

(2)

(3)

(4)

VARIABLES

ATTRIBUTE FINANCIAL1 FINANCIAL2 FINANCIAL4

\begin{tabular}{|c|c|c|c|c|}
\hline HHI_IND & $\begin{array}{c}0.008 \\
(0.785)\end{array}$ & & & \\
\hline HHI_REG & $\begin{array}{c}0.301 \\
(0.612)\end{array}$ & & & \\
\hline NUM & $\begin{array}{c}0.228^{* *} \\
(0.063)\end{array}$ & $\begin{array}{c}0.217^{* *} \\
(0.058)\end{array}$ & $\begin{array}{l}0.220^{* *} \\
(0.057)\end{array}$ & $\begin{array}{c}0.220^{* *} \\
(0.059)\end{array}$ \\
\hline NUMSQ & $\begin{array}{c}-4.986 * * \\
(1.701)\end{array}$ & $\begin{array}{c}-4.801^{* *} \\
(1.636)\end{array}$ & $\begin{array}{c}-4.824^{* *} \\
(1.608)\end{array}$ & $\begin{array}{c}-4.867 * * \\
(1.663)\end{array}$ \\
\hline SMALL & $\begin{array}{c}0.106 \\
(0.612)\end{array}$ & $\begin{array}{c}0.094 \\
(0.615)\end{array}$ & $\begin{array}{c}0.078 \\
(0.615)\end{array}$ & $\begin{array}{c}0.122 \\
(0.622)\end{array}$ \\
\hline AUTOCORR_P & $\begin{array}{c}0.055 \\
(0.715)\end{array}$ & $\begin{array}{c}0.068 \\
(0.709)\end{array}$ & $\begin{array}{c}0.082 \\
(0.711)\end{array}$ & $\begin{array}{c}0.070 \\
(0.713)\end{array}$ \\
\hline VARIANCE_P & $\begin{array}{c}0.288^{* *} \\
(0.074)\end{array}$ & $\begin{array}{c}0.290^{* *} \\
(0.071)\end{array}$ & $\begin{array}{l}0.297 * * \\
(0.072)\end{array}$ & $\begin{array}{c}0.288^{* *} \\
(0.072)\end{array}$ \\
\hline LOSSCARRY_P & $\begin{array}{c}0.617 \\
(0.420)\end{array}$ & $\begin{array}{c}0.616 \\
(0.434)\end{array}$ & $\begin{array}{c}0.615 \\
(0.416)\end{array}$ & $\begin{array}{c}0.619 \\
(0.435)\end{array}$ \\
\hline DI & & $\begin{array}{c}0.026 \\
(0.543)\end{array}$ & & $\begin{array}{c}0.012 \\
(0.544)\end{array}$ \\
\hline LOSSCARRY_S1 & & $\begin{array}{c}0.037 \\
(0.512)\end{array}$ & $\begin{array}{c}0.020 \\
(0.510)\end{array}$ & \\
\hline LOSSCARRY_S2 & & & & $\begin{array}{c}3.148 \\
(3.681)\end{array}$ \\
\hline STDEVPROFIT & & & $\begin{array}{l}-0.120 \\
(0.135)\end{array}$ & \\
\hline Constant & $\begin{array}{c}-10.772 * * \\
(2.338)\end{array}$ & $\begin{array}{c}-10.587 * * \\
(2.019)\end{array}$ & $\begin{array}{c}-10.546^{* *} \\
(2.049)\end{array}$ & $\begin{array}{c}-10.744^{* *} \\
(2.043)\end{array}$ \\
\hline & $\begin{array}{c}4,608 \\
-203.1 \\
0.133\end{array}$ & $\begin{array}{c}4,608 \\
-203.2 \\
0.133\end{array}$ & $\begin{array}{c}4,580 \\
-202.7 \\
0.134\end{array}$ & $\begin{array}{c}4,608 \\
-203.0 \\
0.134\end{array}$ \\
\hline
\end{tabular}

Robust standard errors in parentheses. All egressions include region and industry dummies. ** $\mathrm{p}<0.01,{ }^{*} \mathrm{p}<0.05,+\mathrm{p}<0.1$ 


\section{Appendix}

Table A1

\section{Data definition}

\begin{tabular}{|c|c|c|c|}
\hline Variable name & Definition & Source & $\begin{array}{l}\text { Time } \\
\text { variant? }\end{array}$ \\
\hline PARTICIPATION & An indicator variable: 1 if elected to file a consolidated return; 0 otherwise & $\begin{array}{l}\text { Partners Inc. and } \\
\text { various securities } \\
\text { reports }\end{array}$ & Y \\
\hline AUTOCORR_P & $\begin{array}{l}\text { A partial autocorrelation coefficient estimated from an OLS on a parent } \\
\text { company's earning ratio (nfinancialfp01001) on its first lag and a constant }\end{array}$ & NEEDS & $\mathrm{N}$ \\
\hline VARIANCE_P & $\begin{array}{l}\text { A standard deviation of residuals from the OLS regression for obtaining } \\
\text { autocorrelation in a parent's earning ratio }\end{array}$ & NEEDS & $\mathrm{N}$ \\
\hline NUM & $\begin{array}{l}\text { The number of subsidiaries within a corporate group. The square term } \\
\text { included in regressions is divided by } 1,000 \text {. }\end{array}$ & ACD & $\mathrm{Y}$ \\
\hline \multicolumn{4}{|c|}{ Within-group correlation } \\
\hline HHI_IND & $\begin{array}{l}\text { A Herndahl-Hirschman Index on the concentration of business activities } \\
\text { within a corporate group. The classification of business activities is based on } \\
\text { the 2-digit industry code. }\end{array}$ & ACD & $\mathrm{Y}$ \\
\hline HHI_REG & $\begin{array}{l}\text { A Herndahl-Hirschman Index on the concentration of head-quarter location } \\
\text { within a corporate group. }\end{array}$ & ACD & $\mathrm{Y}$ \\
\hline CR1_IND, CR3_IND & A share of the top (or top 3) business activity within a corporate group & ACD & $\mathrm{Y}$ \\
\hline CR1_REG, CR3_REG & A share of the top (or top 3) business location within a corporate group & ACD & $\mathrm{Y}$ \\
\hline DI & $\begin{array}{l}\text { An absolute value of a diffusion index which is a share of profitable members } \\
\text { less a share of loss-making members }\end{array}$ & ACD & $\mathrm{Y}$ \\
\hline STDEVPROFIT & The standard deviation of profit-to-sales ratios within a corporate group & ACD & Y \\
\hline \multicolumn{4}{|l|}{ Tax provisions } \\
\hline LOSSCARRY_P & $\begin{array}{l}\text { An indicator variable: } 1 \text { if a parent company reported a loss within past } 7 \\
\text { years (nfinancialfc } 058 \text { ); } 0 \text { otherwise }\end{array}$ & NEEDS & $\mathrm{Y}$ \\
\hline LOSSCARRY_S1 & $\begin{array}{l}\text { The number of wholly-owned subsidiaries reporting losses in previous } \\
\text { available sample divided by the number of wholly-owned subsidiaries }\end{array}$ & ACD & $\mathrm{Y}$ \\
\hline LOSSCARRY_S2 & $\begin{array}{l}\text { The total amount of losses made by wholly-owned subsidiaries in previous } \\
\text { available sample divided by parent sales. Winsorized at the } 0.5 \% \text { level in each } \\
\text { tail of the distribution. }\end{array}$ & ACD & $\mathrm{Y}$ \\
\hline SMALL & $\begin{array}{l}\text { The number of small wholly-owned subsidiaries (paid-up capital at or less } \\
\text { than } 100 \text { million) divided by the number of wholly-owned subsidiaries }\end{array}$ & ACD & $\mathrm{Y}$ \\
\hline \multicolumn{4}{|l|}{ Control variables } \\
\hline AGE & The age of a parent company & ACD & $\mathrm{Y}$ \\
\hline ROE & $\begin{array}{l}\text { Return on equity of a parent company (nfinancialfp01147). Winsorized at the } \\
0.5 \% \text { level in each tail of the distribution. }\end{array}$ & NEEDS & $\mathrm{Y}$ \\
\hline LNASSETS & log of parent assets (nfinancialfb067) & NEEDS & $\mathrm{Y}$ \\
\hline
\end{tabular}


Table A2

Group tax systems in the OECD

\begin{tabular}{|c|c|c|}
\hline Country & CFR & Loss Transfer \\
\hline 1 Australia & $\mathrm{y}$ & \\
\hline 2 Austria & $\mathrm{y}$ & \\
\hline 3 Belgium & & \\
\hline 4 Canada & & \\
\hline 5 Chile & & \\
\hline 6 Czech Republic & & \\
\hline 7 Denmark & $\mathrm{y}$ & \\
\hline 8 Estonia & & \\
\hline 9 Finland & & $\mathrm{y}$ \\
\hline 10 France & $\mathrm{y}$ & \\
\hline 11 Germany & $\mathrm{y}$ & \\
\hline 12 Greece & & \\
\hline 13 Hungary & & \\
\hline 14 Iceland & $\mathrm{y}$ & \\
\hline 15 Ireland & & $\mathrm{y}$ \\
\hline 16 Israel & & \\
\hline 17 Italy & $\mathrm{y}$ & \\
\hline 18 Japan & $\mathrm{y}$ & \\
\hline 19 Korea & $\mathrm{y}$ & \\
\hline 20 Luxembourg & $\mathrm{y}$ & \\
\hline 21 Mexico & $\mathrm{y}$ & \\
\hline 22 Netherlands & $\mathrm{y}$ & \\
\hline 23 New Zealand & $\mathrm{y}$ & $\mathrm{y}$ \\
\hline 24 Norway & & $\mathrm{y}$ \\
\hline 25 Poland & $\mathrm{y}$ & \\
\hline 26 Portugal & $\mathrm{y}$ & \\
\hline 27 Slovak Republic & & \\
\hline 28 Slovenia & & \\
\hline 29 Spain & $\mathrm{y}$ & \\
\hline 30 Sweden & & $\mathrm{y}$ \\
\hline 31 Switzerland & & \\
\hline 32 Turkey & & \\
\hline 33 United Kingdom & & $\mathrm{y}$ \\
\hline 34 United States & $\mathrm{y}$ & \\
\hline Count & 14 & 6 \\
\hline Percentage & $(0.41)$ & \\
\hline
\end{tabular}

Notes: Tabulation based on Onji and Vera (2011) 